\title{
REVISION AND DISTRIBUTION OF LIPARIS SPECIES (ORCHIDACEAE) IN AMUR REGION (RUSSIA)
}

\author{
Elena I. Terentieva ${ }^{1}$, Tatyana I. Varlygina ${ }^{1}$, Galina F. Darman ${ }^{2}$, \\ Galina V. Degtjareva ${ }^{1}$, Sergey V. Efimov ${ }^{1}$, Tagir H. Samigullin ${ }^{1}$ \\ ${ }^{1}$ Lomonosov Moscow State University, Russia \\ e-mail:el.terenteva@mail.ru,tat-varlygina@yandex.ru,efimov-msu@yandex.ru \\ ${ }^{2}$ Botanical Garden-Institute of FEB RAS, Russia \\ e-mail:gfdarman@yandex.ru
}

Received: 16.04.2020. Revised: 07.06.2020. Accepted: 29.06.2020.

\begin{abstract}
In July 2018, in the Khingan State Nature Reserve and Muravyevskiy Park of Sustainable Development, we conducted the study of Liparis populations and preliminary determining the orchid individuals collected. In the family Orchidaceae, Liparis is one of the most difficult genera in terms of systematics. Observations in nature, research of herbarium specimens and literature demonstrate the considerable intraspecies variability in morphological traits. Therefore, to assess the taxonomic position of orchids from natural populations, we collected parts of the plants for further molecular-phylogenetic research. In total, we included 110 samples in the analysis. As a molecular marker, we used the internal transcribed spacers (ITS1-5.8S-ITS2) of 18S-26S nuclear ribosomal DNA. At the obtained phylogenetic tree, samples from the studied populations formed separate and clearly supported clades, that confirms their naturalness. ITS sequences of the analysed plants of each clade have groupspecific substitutions, which mark their position on the phylogenetic tree. Analysis of both morphological traits and molecular-phylogenetic data allowed conducting species determination of plants from the genus Liparis. According to botanical literature, in the Amur region, two species were known: Liparis japonica and L. makinoana. The investigation of Liparis populations found in the field together with analysis results of morphological and molecular-phylogenetic data demonstrated that in the study area, besides L. japonica and L. makinoana, there are L. kumokiri and one more taxon, which could be a new species needed to be described in future. We clarified the distribution of these Liparis species in the study area by finding their new locations. The status of each population for studied species was appropriate at most of the locations. We noted the appropriate fruiting and offspring presence. At the studied location, permanent study plots could be established for conducting of further population-based studies. The obtained data on the status of plant populations will be used in the work on new editions of Red Data Books. In the study area, the presence of Liparis makinoana have not been confirmed by data of molecular-phylogenetic analysis.
\end{abstract}

Key words: molecular-phylogenetic study, morphological traits, phylogeny, population status, Protected Area, rare species, Red Data Book

\section{Introduction}

The genus Liparis Rich. (tribe Malaxideae Lindl.) includes about 250-300 species distributed predominantly in the tropics of the Old World. In Russia, six Liparis species are known. Liparis loeselii (L.) Rich is distributed in European Russia and Siberia. Liparis japonica (Miq.) Maxim., L. krameri Franch. \& Savat., L. kumokiri F. Maek., L. makinoana Schlechter and L. sachalinensis Nakai are known from the Russian Far East (Vakhrameeva et al., 2014).

This genus is still one of the most difficult Orchidaceae genera in terms of systematics. In-nature observations, investigation of data from herbaria and literature have demonstrated a considerable intraspecies variability in morphological parameters of Liparis species (Shibneva, 2007, 2011; Efimov, 2010). This makes it difficult or even impossible to distinguish certain species within this genus. In addition, the natural ranges of some Liparis species are overlapped, which additionally confuses their deter- mination. The high degree of intraspecies polymorphism and a relatively small number of morphological traits significant for species determination make the limits between Liparis species by the discussion topic (Maekawa, 1971; Dressler, 1981; Kim \& Kim, 1986; Shibneva, 2004, 2007, 2008; Tsutsumi \& Yukawa, 2008; Efimov, 2010). The applying of molecular-phylogenetic methods together with morphological data allow approaching a new level in solving issues related to morphology, systematics and phylogeny of the genus Liparis. A worldwide active investigation of the genus Liparis is currently underway by comparing of sequences of rDNA internal transcribed spacers, as well as using other molecular markers, primarily encoding and non-coding regions of chloroplast DNA (genes matK, $y c f 1$, spacers $\operatorname{trn} \mathrm{L}-\mathrm{trn} \mathrm{F}$ and $\operatorname{trnS}-\operatorname{trn} \mathrm{G}$ ) (Dressler, 1993; Cameron, 2005; Tsutsumi et al., 2007, 2008a,b; Lee et al., 2010; Li \& Yan, 2013; Su et al., 2014, 2015; Terentieva et al., 2016, 2018, 2019). 
Previously (Vyshin, 1996; Starchenko \& Darman, 2002; Vakhrameeva et al., 2014), only two Liparis species (L. makinoana Schlechter and $L$. japonica (Miq.) Maxim.) had been noted in the Amur region. They are included in the Red Data Book of the Russian Federation (2008) and the Red Data Book of the Amur region (2019). In addition, L. japonica is protected in the Khingan State Nature Reserve (Kudrin \& Yakubov, 2013) and in the Amur Branch of the Botanical Garden-Institute of FEB RAS (Starchenko \& Darman, 2002).

In July 2018, Terentieva et al. (2019) found for the first time Liparis plants in the forest area of the Muravyevskiy Park of the Sustainable Development during a botanical field trip. The found plants could not belong to any of the Liparis species known in the Amur region on the basis of morphological traits. In the field, the individuals, having green flowers, were preliminary named as L. kumokiri, while plants with coloured flowers left non-determined. The same situation occurred in the Khingan State Nature Reserve.

The present study aimed to clarify the list of Liparis species and their distribution in the Amur region using morphological data and molecularphylogenetic methods. The molecular phylogenetic reconstruction is based on the previous phylogenetic analysis of Terentieva et al. (2019), being considerably supplemented by new samples and taxa from the GenBank database.

\section{Material and Methods}

The material for the study was collected in July 2018 during a botanical field trip of the researchers of Moscow State University in two Protected Areas of the Amur region (Russia), the Muravyevskiy Park of the Sustainable Development (Tambovskiy district) and two sites of the Khingan State Nature Reserve (Arkharinskiy district). In addition, we collected samples outside Protected Areas: 1) in the surroundings of the villages Ivanovka and Bogoslovka (Ivanovskiy district); 2) on the gold slag disposals (Blagoveshchenskiy district); 3 ) in the forest massif near the Amur Branch of the Botanical GardenInstitute of FEB RAS (Fig. 1).

According to geobotanical zoning, the $\mathrm{Mu}-$ ravyevskiy Park of the Sustainable Development belongs to the southern steppe zone and is represented by forests, shrubs, marshes and meadows. The flora of vascular plants includes 614 species (Darman, 2015). Liparis species have been studied in the forested part of the Protected Area.
In the Khingan State Nature Reserve, we conducted the research in the Antonovskoe forestry (surroundings of Lake Kleshinskoe) and in the Khinganskoe forestry (cordon Karapcha), and in the adjacent area, i.e. in the vicinity of Lake Dolgoe. Khingan State Nature Reserve is located at the southeastern edge of the Amur region, on the Khingan-Arkharinsk Lowland. According to Miskina (1971), the mountain area of the Protected Area (Khinganskoe forestry) belongs to the Far East broad-leaved landscape type, while its flat part (Antonovskoe forestry) belongs to the Far East forest-steppe landscape type.

In the study area, we surveyed all sites suitable for Liparis species using the route method. In the found populations, we measured morphological traits (which are significant for species determining) of plant individuals (Nevskiy, 1935; Vyshin, 1996; Shibneva, 2004, 2007, 2008; Efimov, 2010). We determined the plant height, length of inflorescences and ovaries, number of flowers, degree of the lip curling, length and width of leaf plate. Population-based studies have been carried out on the established transects (Rabotnov, 1950). Ontogenetic stages (age groups) of Liparis individuals were distinguished according to Tatarenko (1996) with our modifications. In the studied populations, we distinguished the following age groups: $\mathrm{j}$ - juvenile individuals; im - immature individuals; $\mathrm{v}$ - virginile (mature vegetative) individuals including non-flowering generative plants; $\mathrm{g}$ - generative individuals.

Since the known intraspecies variability in morphological traits of Liparis species does not allow a reliable identification of species in nature, we applied the molecular phylogenetic approach. Because all Liparis species are threatened, the collection of samples for the analysis was performed by harvesting only small parts of plants without digging the whole plant. For molecular-phylogenetic analysis, we used small parts of leaves from 32 samples of plant individuals originated from the studied Liparis populations. It was especially relevant for the populations where the species identification was almost impossible because generative individuals were absent, or in the stages of budding or fruiting. Some parts of vegetative and generative parts of plants were saved as herbarium vouchers with indication of the sampling locations (Electronic Supplement 1). In addition, the analysis included samples stored in herbariums (MW, LE, MAG, ABGI) and collected during 2015-2018 in the field trips through the Russian Far East (Primorsky Krai) (Electronic Supplement 1). 


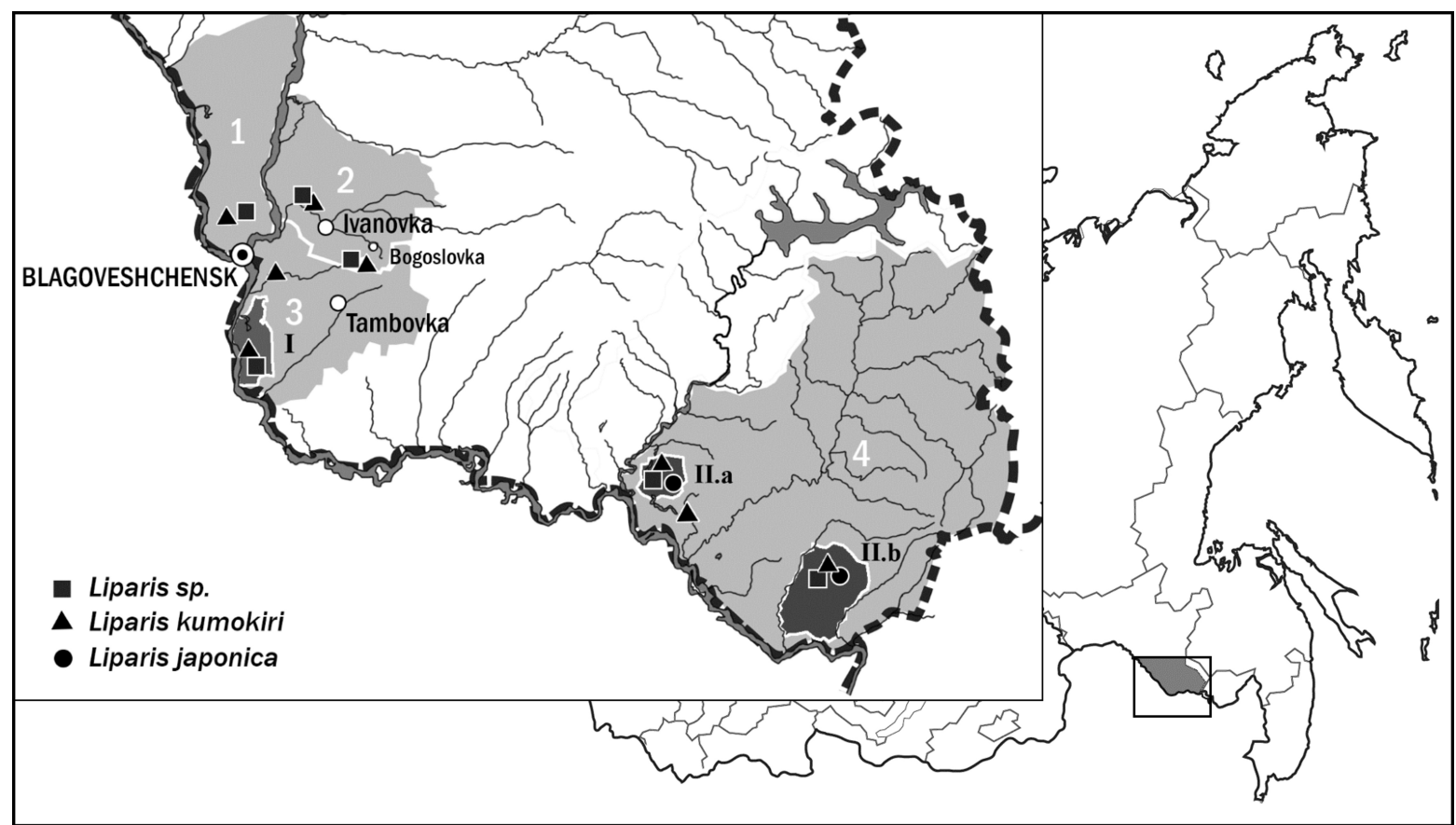

Fig. 1. Locations of Liparis species in the study area (Amur region, Russia). Designations: 1 - Blagoveshchenskiy district, 2 - Ivanovskiy district, 3 - Tambovskiy district, 4 - Arkharinskiy district; I - Muravyevskiy Park of the Sustainable Development; II - Khingan State Nature Reserve (a - Antonovskoe forestry, b - Khinganskoe forestry).

As a molecular marker in the molecular-phylogenetic analysis, we used internal transcribed spacers (ITS1-5.8S-ITS2) of 18S-26S nuclear ribosomal DNA. DNA extraction, amplification and sequencing the spacers ITS1-5.8S-ITS2 were conducted according to Valiejo-Roman et al. (2002). The obtained PCR products were sequenced on both strands. Then we investigated chromatograms of ITS1-5.8S-ITS2 region using software Chromas Lite v. 2.3, where for the analysed species we did not find double peaks and discrepancies through reads the nucleotide sequences from both forward and reverse primers.

We determined ITS sequences for 47 samples of the Liparis representatives (living plants collected in nature and herbarium specimens). To conduct the molecular-phylogenetic analysis, we additionally included 59 nucleotide ITS sequences of 22 (primarily closely related) Liparis species from the database GenBank (https://www.ncbi.nlm.nih.gov/ nucleotide/). For this purpose, we used the results of other authors (Cameron, 2005; Tsutsumi et al., 2007; Chen et al., 2009; Lee et al., 2010; Li et al., 2013; Su et al., 2014, 2015). In addition, we included ITS sequences of three Malaxis species ( $M$. spicata Sw., M. brachypoda Fernald, M. monophyllos (L.) Sw.), as this genus is closely related to the genus Liparis. In total, the data set of the molecular-phylogenetic analysis included 110 accessions from Russia, Korea, Japan, China, Hawaii Islands. The newly obtained nucleotide sequences for the genus Liparis are annotated in the database GenBank (Electronic Supplement 1).

The nucleotide sequences of the analysed samples were aligned using the program MUSCLE (Edgar, 2004). The demonstration and manual adjustment of the aligned results were conducted using the program BioEdit v. 5.0.9. (Hall, 1999). The alignment of 110 nucleotide sequences of the ITS15.8S-ITS2 regions resulted in a matrix of 732 positions. Of them, 369 were constant, 254 parsimony informative, and 109 parsimony non-informative.

To construct the phylogenetic tree, we used the method of maximum parsimony realised using PAUP* version 4.0b8 (Swofford, 2003). The heuristic search was used for finding the most parsimonious tree. The non-parametric bootstrap analysis (Felsenstein, 1985) was performed to assess the degree of support for particular clades (100 bootstrap replicates).

Bayesian analysis of molecular data was performed using the program MrBayes v. 3.2 (Ronquist et al., 2012). 5000000 generations were performed using Markov chain Monte Carlo. The number of simultaneously generated chains was four. A posterior probability of a tree node was calculated as the frequency of the corresponding node in the trees, which were obtained after the likelihood converged to equilibrium through the generation of Markov chains.

As an outgroup, we used Dendrobium crumenatum Sw., selected on the basis of research of Cameron (2005). Different loci obtained by two 
methods are not similar, but congruent, in the main tree topologies. In the paper, we present a consensus phylogenetic tree constructed using Bayesian method (maximum parsimony tree is represented in Electronic Supplement 2: Fig. 1S).

\section{Results and Discussion Morphological and population analysis}

Table 1 presents data on the morphological traits of three Liparis species according to the botanical literature (Nevskiy, 1935; Tatarenko, 1996; Vyshin, 1996; Shibneva, 2004, 2007, 2008; Efimov, 2010). Data for Liparis sp. were obtained by us during the field studies in the Amur region. Table 1 demonstrates that actually there are no clear traits allowing us to identify these Liparis species. All morphological traits are considerably variable. Their values could be overlapping for different species and depend on the habitat conditions.

\section{Muravyevskiy Park of the Sustainable Development}

The orchid plants found in the forest of the Muravyevskiy Park of the Sustainable Development considerably differed from each other. On the basis of the morphology (Table 2), one of the specimens was identified as Liparis kumokiri, because values of its morphological traits (height is until 25 $\mathrm{cm}$; there is no long petiole; relatively short inflorescence with yellow-greenish flowers, and narrow, strongly curled lip) were consistent with literature data (Shibneva, 2008, 2011; Efimov, 2010). Some individuals were named as Liparis sp., because their height, size, shape, denser texture of the leaf, and the form of the lip were different to other Liparis species. The populations of both species were located by dense groups being different in terms of abundance and area. At the same time, L. kumokiri occurs more commonly. In comparison with $L$. kumokiri, plants named as Liparis sp. had higher shoots, brownish or purple colouration of flowers, a higher number of flowers, ovary length, leaf plate size and darker colouration of leaves (Table 2).

Therefore, in the Muravyevskiy Park of the Sustainable Development, we found for the first time for the Amur region the species L. kumokiri and plants treated by us as Liparis sp. We were going to test our assumptions using molecular-phylogenetic studies. Liparis kumokiri was noted on two sites of the Muravyevskiy Park of the Sustainable Development. The first of them is located in a planted pine (Pinus koraiensis Siebold \& Zucc.) forb-grass forest (age of about 17 years) with sparse herb cover, located nearby administrative buildings. On this site, a small (three generative individuals) group of $L$. kumokiri was found. The main populations of both Liparis species have been noted on the second site, located $1 \mathrm{~km}$ from the first site. The first L. kumokiri micropopulation was located on the edge of pine (Pinus koraiensis) forbs grass forest and aspen (Populus tremula L.) forbs grass forest with $20 \%$ herb cover. This population covered an area of $8 \mathrm{~m}^{2}$ with a density of 9.5 individuals per $1 \mathrm{~m}^{2}$. Its ontogenetic spectrum was represented by all age groups: $23.7 \% \mathrm{j}+18.4 \% \mathrm{im}+$ $23.7 \% \mathrm{v}+34.2 \% \mathrm{~g}$. Thus, this micropopulation was full-membered and normal (according to Rabotnov, 1950) with good reproduction due to young individuals $(j+i m)$ included $42.1 \%$ of all plants. In the sparse forbs dead-cover pine forest with $15 \%$ herb cover, we found other large micropopulations of L. kumokiri (more than 200 plants) and Liparis sp. (more than 100 plants). In these micropopulations, we found a good level of reproduction, i.e. $25 \%$ of young individuals for L. kumokiri, and $33.3 \%$ of young individuals for Liparis sp. The Liparis kumokiri density was 12.8 individuals per $1 \mathrm{~m}^{2}$, while Liparis sp. had 5.4 individuals per $1 \mathrm{~m}^{2}$. Therefore, all Liparis micropopulations are full-membered, sustainable and normal (according to Rabotnov, 1950), and the presented above parameters indicated a good vital status of them. During further studies in the Amur region, population of these two species were found at some locations in the Antonovskoe forestry and Khinganskoe forestry of the Khingan State Nature Reserve and in adjacent areas (Lake Dolgoe) (Arkharinskiy district). In addition, we registered them also outside Protected Areas, in some other districts of the Amur region (Ivanovskiy district and Blagoveshchenskiy district), and nearby the Botanical Garden in the town Blagoveshchensk (Fig. 1).

Table 1. Some morphological traits of generative individuals of Liparis species

\begin{tabular}{|l|c|c|c|c|c|c|c|}
\hline \multicolumn{1}{|c|}{ Species } & $\begin{array}{c}\text { Height, } \\
\mathrm{cm}\end{array}$ & $\begin{array}{c}\text { Inflorescence } \\
\text { length, } \mathrm{cm}\end{array}$ & $\begin{array}{c}\text { Leaf length, } \\
\mathrm{cm}\end{array}$ & $\begin{array}{c}\text { Leaf width, } \\
\mathrm{cm}\end{array}$ & $\begin{array}{c}\text { Number of } \\
\text { flowers }\end{array}$ & Leaf petiole & Flower colour \\
\hline Liparis japonica $^{*}$ & $25-35$ & until 20 & until 10 & $5-7$ & $9-25$ & $8 \mathrm{~cm}$, winged & greenish-yellow, rare brownish \\
\hline Liparis kumokiri $^{*}$ & $10-25$ & 7 & until 12 & $3-5$ & $5-15$ & short, amplexicaul & greenish-yellow \\
\hline Liparis makinoana $^{*}$ & $15-25$ & $10-17$ & $6-8$ & $3-5$ & $20-25$ & short, amplexicaul & from greenish to purple \\
\hline Liparis sp. & $23-58$ & until 20 & until 12 & $5-7$ & $6-25$ & short, amplexicaul & from brownish to purple \\
\hline
\end{tabular}

Note: $*$ - literature data. 
Table 2. Morphological traits for generative individuals of Liparis species in the Muravyevskiy Park of the Sustainable Development

\begin{tabular}{|c|c|c|c|c|c|c|c|}
\hline \multirow{3}{*}{ Species } & \multicolumn{7}{|c|}{ Traits } \\
\hline & \multicolumn{2}{|c|}{ Height, $\mathrm{cm}$} & \multicolumn{2}{|c|}{ Number of flowers } & \multicolumn{2}{|c|}{ Leaf size, $\mathrm{cm}$} & \multirow{2}{*}{ Ovary length, $\mathrm{cm}$} \\
\hline & Average $(n=10)$ & $\min -\max$ & Average $(n=10)$ & $\min -\max$ & Leaf length & Leaf width & \\
\hline Liparis kumokiri & $18.60 \pm 2.54$ & $13-23$ & $14.2 \pm 2.2$ & $9-20$ & $10.20 \pm 0.87$ & $5.70 \pm 0.74$ & $0.70 \pm 0.16$ \\
\hline \begin{tabular}{|l|} 
Liparis $\mathrm{sp}$. \\
\end{tabular} & $29.20 \pm 2.64$ & $23-36$ & $20.5 \pm 3.8$ & $16-25$ & $11.00 \pm 1.10$ & $5.30 \pm 1.25$ & $1.55 \pm 0.22$ \\
\hline
\end{tabular}

\section{Khingan State Nature Reserve}

Both species were registered on several sites in the vicinity of the Lake Kleshinskoe in the Antonovskoe forestry of the Khingan State Nature Reserve. Micropopulations were found in the sparse Siberian birch (Betula platyphylla Sukaczev (= Betula pendula subsp. mandshurica (Regel) Ashburner \& McAll.) forbs forest, birch-oak (Betula platyphylla, Quercus mongolica Fisch. ex Ledeb.) forest with linden (Tilia amurensis Rupr.) undergrowth; willow (Salix sp.) thickets at the forest edge in the Borzi River valley, and other plant communities. Usually, Liparis kumokiri occurred in separate, sparse groups with a maximum density of 8.5 individuals per $1 \mathrm{~m}^{2}$. In the ontogenetic spectrum of micropopulations, young individuals often prevailed $(\mathrm{j}+\mathrm{im}=$ until $54 \%)$. Liparis sp. has been found much rarer, in populations of which young individuals $(j+i m)$ reached until $17 \%$ in sum, while there were $50 \%$ of generative and 33\% mature vegetative individuals (virginile and non-flowering generative individuals). A small L. kumokiri population, containing several low-number (1-7 individuals) groups, has been found nearby the Antonovskoe forestry of the Khingan State Nature Reserve in the Siberian birch (Betula platyphylla) forbs forest on the shore of Lake Dolgoe.

In the Khinganskoe forestry of the Khingan State Nature Reserve, we found two Liparis species inhabiting the low part of hillsides in the Karapcha River valley. The orchid populations were noted in linden (Tilia amurensis) sedge-forbs forest with a mixture of Quercus mongolica and Acer pictum subsp. mono (Maxim.) H.Ohashi with Corylus heterophylla Fisch. ex Trautv. undergrowth with 25$30 \%$ herb cover; in the Acer pictum subsp. mono forest with a mixture of Quercus mongolica and undergrowth of Acer tegmentosum Maxim. and Acer pictum subsp. mono with sparse herb cover containing species as Hemerocallis middendorffii Trautv. \& C.A.Mey., Carex sp., Phryma nana Koidz., Thalictrum aquilegiifolium var. sibiricum Regel \& Tiling and others. As usual, we found small groups of Liparis individuals.
Sometimes, both species occurred in close proximity to each other. In addition, we noted that Liparis sp. prefers more moistured conditions than the other species. Its population (with a total number of 33 plants) is characterised by the predomination of mature individuals $(45.5 \% \mathrm{~g}$ and $21.2 \%$ $\mathrm{v})$, while young individuals were represented in sum about one-third of the total number of individuals. Liparis kumokiri often inhabited the more elevated sites at the middle parts of hillsides. The species grew sparsely, by single individuals or lownumber groups (5-11 plants). The ratio of the mature $(33.3 \% \mathrm{~g}$ and $16.7 \% \mathrm{v})$ and young $(22.2 \% \mathrm{j}$ and $27.8 \% \mathrm{im}$ ) individuals in a population was approximately equal. So, in both Antonovskoe forestry and Khinganskoe forestry of the Khingan State Nature Reserve, the populations of these species are fullmembered, sustainable and normal (according to Rabotnov, 1950) having a good reproduction.

In addition, on the Khingan State Nature Reserve, we found Liparis japonica, which has not been previously known in the Amur region. Single individuals of this species were found in both forestries. In the Antonovskoe forestry, it was recorded in the vicinity of Lake Kleshinskoe, in sparse Siberian birch (Betula platyphylla) forbs forest, having $40 \%$ forest stand cover and $25 \%$ projective cover of the herb layer. Low-number groups of L. japonica were found in the Khinganskoe forestry (Fig. 1). At this location, the species inhabits broad-leaved forest with sparse herb cover on the hillside in the Karapcha River valley. Liparis japonica occurs considerably rarer than both previous species. Its populations are low in number, often non-full-membered; its reproduction was not found.

Table 3 presents morphological traits of all $\mathrm{Li}$ paris species found in the Khingan State Nature Reserve. We clearly see the differences in these data between species as well as between populations situated under different habitat conditions. For example, in the Khinganskoe forestry, the average height of generative individuals was more than in the Antonovskoe forestry. Perhaps, it is caused by higher values of soil moisture and richness. 
Table 3. Morphological traits of generative individuals for the studied Liparis species in the Khingan State Nature Reserve

\begin{tabular}{|c|c|c|c|c|}
\hline \multirow{3}{*}{ Species } & \multicolumn{4}{|c|}{ Traits } \\
\hline & \multicolumn{2}{|c|}{ Height, cm } & \multicolumn{2}{|c|}{ Number of flowers } \\
\hline & Average $(\mathrm{n}=10)$ & $\min -\max$ & Average $(n=10)$ & $\min -\max$ \\
\hline \multicolumn{5}{|c|}{ Antonovskoe forestry } \\
\hline Liparis kumokiri & $15.7 \pm 2.75$ & $8-23$ & $6.75 \pm 1.88$ & $2-12$ \\
\hline Liparis sp. & $35.7 \pm 7.9$ & $23-42$ & $12.1 \pm 4.1$ & $3-25$ \\
\hline \multicolumn{5}{|c|}{ Khinganskoe forestry } \\
\hline Liparis kumokiri & $20.3 \pm 2.67$ & $16-25$ & $6.7 \pm 1.67$ & $3-10$ \\
\hline Liparis japonica & $36 \pm 2.5$ & $31-40$ & $15.8 \pm 4.75$ & $11-23$ \\
\hline Liparis $\mathrm{sp.}$ & $41.7 \pm 9.9$ & $23-58$ & $14 \pm 6.6$ & $5-25$ \\
\hline
\end{tabular}

In addition, we found that the last year's upright old flowering stems of L. kumokiri with the remains of capsules remained. We did not note this for the other two Liparis species, perhaps, because they are characterised by higher peduncles, which fall and could not be found. The fruits' remains allowed us to conclude on the good level of the fruit productivity of L. kumokiri. According to Gap et al. (2001), the fruit productivity of this species is $86 \%$, although it could be lower, until 10.2-12.2\%. According to Varlygina et al. (2017), in the Kedrovaya Pad' State Nature Reserve, the fruit productivity of Liparis species varied from $30 \%$ to $60 \%$ for $L$. japonica, from $40 \%$ to $65 \%$ for $L$. kumokiri, and from $50 \%$ to $70 \%$ for $L$. krameri. This parameter considerably depends on the weather conditions and presence of pollinators.

We found L. kumokiri and Liparis sp. outside Protected Areas, too. In the vicinity of the village Ivanovka (Ivanovskiy district); planted pine (Pinus koraiensis) forbs forest with undergrowth of Fraxinus mandshurica Rupr. and Betula platyphylla, with Malus baccata (L.) Borkh. and Rubus idaeus subsp. strigosus (Michx.) Focke; forest stand cover is 50\%; projective cover of the herb layer is $10-15 \%$. The second found location was in the vicinity of the village Bogoslovka (Ivanovskiy district), in Siberian birch (Betula platyphylla) forbs forest with dense undergrowth from Corylus heterophylla; forest stand cover is $60 \%$; the total projective cover of the herb layer is $10 \%$. The third location was found on the gold slag disposals and in the oak-birch (Quercus mongolica, Betula platyphylla) forest in the Blagoveshchenskiy district. The fourth location was found in the forest of the town Blagoveshchensk, nearby the Amur Branch of the Botanical GardenInstiture of FEB RAS. The populations of these species were interspersed along the wide area.

\section{Molecular-phylogenetic analysis}

In the obtained molecular-phylogenetic trees, the analysed samples of Liparis species formed four highly supported clades (I, II, III, IV). This confirms their natural origin (Fig. 2).

Clade I consists of samples collected in the $\mathrm{Mu}-$ ravyevskiy Park of the Sustainable Development, vicinities of town Blagoveshchensk, village Bogoslovka and village Ivanovka, in the Khingan State Nature Reserve (Antonovskoe and Khinganskoe forestries), in the vicinity of Lake Dolgoe, and, finally, samples of L. kumokiri and L. japonica extracted from herbarium collections (MW and LE). In addition, this clade includes taxa from the database GenBank: $L$. kumokiri, L. koreana (Nakai) Nakai, L. fujisanensis F. Konta \& S. Matsumoto, L. hawaiensis H. Mann, and recently described species $L$. pterosepala N.S. Lee, C.S. Lee \& K.S. Lee, L. koreojaponica Tsutsumi, T. Yukawa, N.S. Lee, C.S. Lee \& M. Kato, and L. purpureovittata Tsutsumi, T. Yukawa \& M. Kato, collected in Korea, Japan, and Hawaii Islands (Cameron, 2005; Tsutsumi et al., 2007, 2008a,b; Lee et al., 2010). Clade I is represented by a high number of difficult to distinguish species, which are characterised by polymorphism and blurred species boundaries. According to the analysis of ITS sequences, the samples collected in nature and originally identified as L. kumokiri, L. japonica and L. makinoana were located in different subclades of clade I, not always meeting their original identification on the basis of morphological traits.

Clade I consists of three subclades A, B and C. Inside the clade, all nodes have high values of bootstrap support and posterior probability. The species L. pterosepala, L. hawaiensis, and L. purpureovittata occupy separate positions in the basal part of the clade that indicates the highest divergence level of these species compared to other representatives. In clade I, the divergence level between samples in ITS-sequences, expressed in $p$-distances, is low and equal to $0.0-1.7 \%$ indicating their closely relations and corresponding with other studies (Tsutsumi et al., 2007, 2008a,b; Lee et al., 2010; Su et al., 2015; Terentieva et al., 2018). 


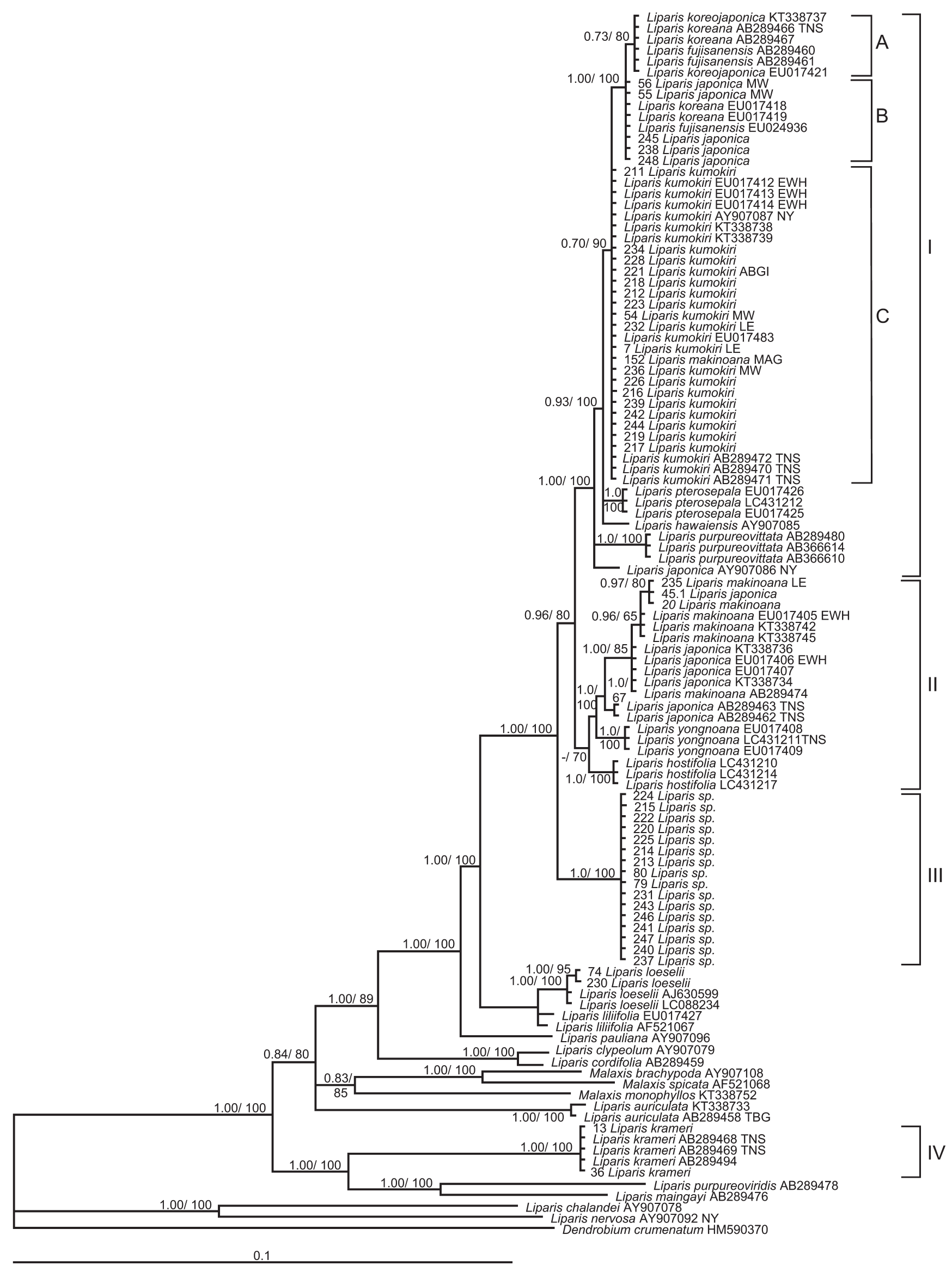

Fig. 2. Phylogenetic relationship in Liparis as indicated by a majority-rule consensus tree of 5000000 trees from Bayesian analysis on the basis of nrDNA ITS1-5.8S-ITS2 dataset, using the TBR model. Numbers indicate node support (posterior probability values / maximum parsimony bootstrap values). Only bootstrap values $>50$ and posterior probability values $>0.70$ are shown. 
The species L. koreana (AB289465-467) from Japan, L. fujisanensis (AB289460-61) and L. koreojaponica from Korea form a highly supported subclade A, which is well consistent with molecular-phylogenetic data (Tsutsumi et al., 2007, 2008b; Lee et al., 2010). Our samples from the Khingan State Nature Reserve $(238,245,248)$, are originally identified on the basis of morphological traits as L. kumokiri $(238,248)$ and L. makinoana (245), united in subclade B, together with herbarium specimens of $L$. japonica (MW), L. koreana (EU017418-19) (EWH), and L. fujisanensis (EU024936) (EWH). This subclade has a sister position with a group of species L. koreana (AB289466467), L. fujisanensis (AB289460-61) and L. koreojaponica (EU017421, KT338737) from subclade A. In the phylogenetic tree, samples of $L$. koreana and $L$. fujisanensis are divided between subclasses A and B. Analysis of ITS sequences demonstrates that all samples in subclade A have only one synapomorphic transition $\mathrm{C} \rightarrow \mathrm{T}$ in position 809 (Table 4), which indicates a close relation of species included in these subclades.

We have selected herbarium specimens of $L$. japonica ([MW0047467], [MW0047469]) as marker species (the type specimen of this species is lost). Morphological traits of these specimens (height of plant, leaf shape, leaf width, shape, length and width of lip, inflorescence length) correspond to diagnostic traits indicated in literature (Nevskiy, 1935; Vyshin, 1996; Vakhrameeva et al., 2014). By comparing ITS sequences of samples in subclade $\mathrm{B}$, we identified two synapomorphic transitions, $\mathrm{C} \rightarrow \mathrm{T}$ and $\mathrm{C} \rightarrow \mathrm{A}$ (Table 4), which differ taxa of this subclade from taxa of the sister subclade $\mathrm{C}$. The obtained molecular-phylogenetic data allowed us to assume that samples of subclade B are represented by one species L. japonica, despite to some morphological differences between them.

However, according to literature (Ohwi, 1965; Shibneva, 2008, 2011), plants considered in Russia as L. japonica, do not correspond to L. japonica from Japan according to diagnostic traits. This is consistent with results of our molecular-phylogenetic analysis, where samples of L. japonica (EU01740607, KT338734, KT338736, AB289462-63) from Japan and samples of L. japonica (238), 245, 248 (MT276431-32) from Russia were in different clades, distant from each other. Samples of $L . j a-$ ponica from Japan were grouped with L. makinoana in a clade II with high support. It is consistent with results of our previous study (Terentieva et al., 2018) and with data of other authors (Tsutsumi et al., 2007; Lee et al., 2010; Su et al., 2015). Thus, the problem of L. japonica identification in Russia requires a separate complex analysis.

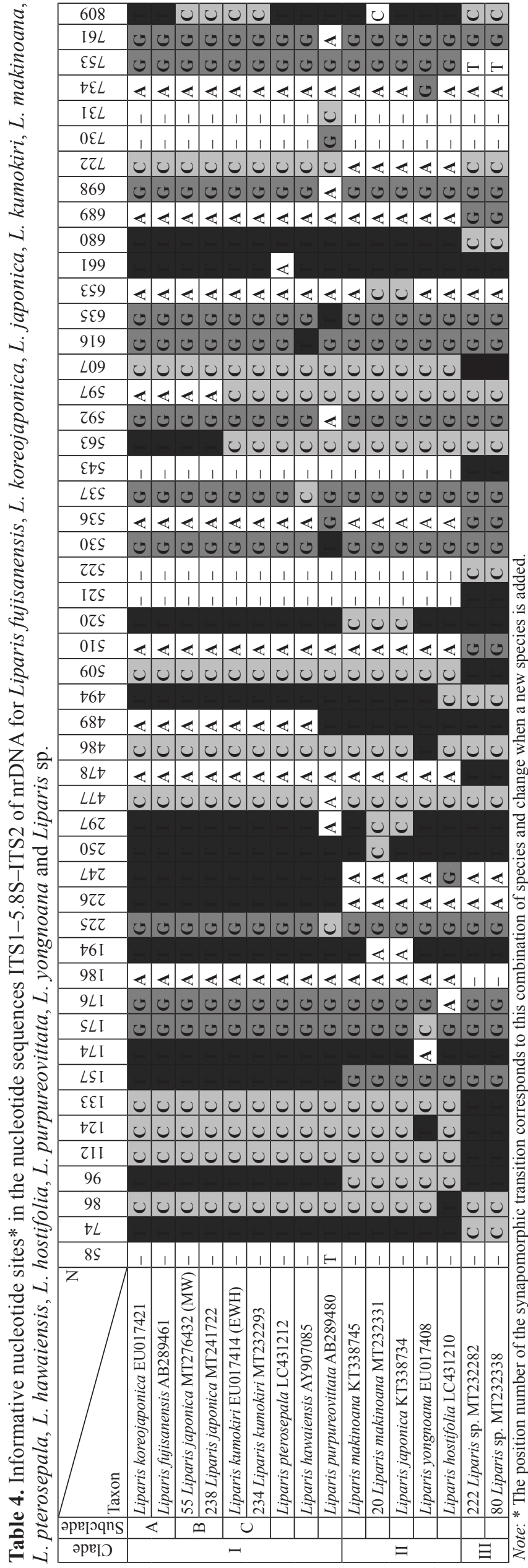


Subclades C has a sister position with subclade B. Subclade C consists of samples collected in the Khingan State Nature Reserve $(239,242$, 244), the Muravyevskiy Park of the Sustainable Development $(211,212,217,218,219)$, in the vicinities of the town Blagoveshchensk (223), village Bogoslovka $(234,228)$, and samples of $L$. kumokiri from herbarium collections (MW, LE, EWH, NY). We selected samples of L. kumokiri from herbarium collections MW and LE on the basis of qualitative traits, which correspond to the species description accepted in Russian literature (Nevskiy, 1935; Vyshin, 1996). According to literature (Ohwi, 1965; Kim \& Kim, 1986; Shibneva, 2004, 2007, 2008; Chen, 2009), values of morphological traits of L. kumokiri distributed in the south of the Russian Far East correspond to those in this species from Korea, Japan and China. Despite to some differences, our samples also correspond to the variation range in diagnostic traits of L. kumokiri confirming their presence in subclade $\mathrm{C}$ together with other samples from Russia and other countries.

Clade III is formed by samples of L. makinoana, L. japonica, L. hostifolia Koidz. \& Nakai and L. yongnoana N.S. Lee, C.S. Lee \& K.S. Lee from Japan, Korea and China (Genbank), herbarium specimen of L. makinoana (LE), plants collected by us in the Land of Leopard State Nature Reserve and Ussuri State Nature Reserve (Primorsky Krai, Russia) in 2015, and, finally, specimens collected in the Amur region in 2018. However, no one of the analysed samples from the Amur regions has been grouped with L. makinoana.

All samples of Liparis sp. from the Khingan State Nature Reserve (237, 240, 241, 243, 246, 247), Muravyevskiy Park of the Sustainable Development $(213,214,215)$, vicinities of the town Blagoveshchensk (220, 227), village Ivanovka $(222,224)$, village Bogoslovka (225, $230,231)$ with samples $(79,80)$ from Terneyskiy district and Lazovskiy district (Primorsky Krai, Russia) form a separate clade III with a high bootstrap support (100\%) and a high posterior probability (1.0).

In the Terneyskiy district and Lazovskiy district, samples of Liparis $(79,80)$ were collected from fruiting plants, which made their identification difficult. Plants collected in the Amur region were flowering. But the set of their morphological traits (Table 1) did not allow us to identify them until the species level, either. The conducted molecular-phylogenetic analysis has demonstrated that all samples in the clade III had identical ITS sequences with synapomorphic transitions (Table 4), which determine a position of taxa of this clade on the phylogenetic tree. Samples of clade III occupied a distant position from taxonomically closely related species Liparis kumokiri, L. japonica, L. makinoana, L. koreojaponica, L. pterosepala, L. koreana, L. fujisanensis, L. hawaiensis, L. hostifolia, L. purpureovittata, and L. yongnoana, which were included into other clades.

The species Liparis loeselii (L.) Rich., L. liliifolia (L.) A.Rich. \& Lindl., L. pauliana Hand.Mazz., L. clypeolum Lindl., L. auriculata Blume \& Miq., L. krameri Franch. \& Sav., L. purpureoviridis Burkill \& Holttum, L. maingayi Ridl., L. chalandei Finet, L. cordifolia Hook.f., and L. nervosa (Thunb.) Lindl. occupy an isolated position or form separated clades in the basal part of the phylogenetic tree, which is consistent with both morphological and molecular-phylogenetic data of other studies (Cameron, 2005; Li \& Yan, 2013; Su et al., 2014, 2015; Cheng et al., 2016).

Thus, the results of the molecular-phylogenetic analysis together with data of morphological studies allow us to assume that samples from Liparis population in clade III (so-called Liparis sp.) could have a species status, which requires additional investigations.

\section{Conclusions}

According to the results of the molecular-phylogenetic analysis, Liparis samples collected in the Amur region and extracted from the database GenBank were arranged along the phylogenetic tree according to the species affinity. All closely related taxa are placed into sister clades and subclades which is in accordance with literature data.

The comparative-morphological studies with data of molecular-phylogenetic analysis allowed conducting taxonomic identification of Liparis plants collected in the Amur region. We have demonstrated the presence of Liparis kumokiri in the Amur region, as well as of presumably a new species, which we provisionally indicated as Liparis $\mathrm{sp}$. A final conclusion for this issue requires further complex investigations.

We have confirmed the presence of Liparis japonica in the Khingan State Nature Reserve, and clarified the distribution of all found Liparis species in the Amur region. In addition, we revealed new locations of these species in the Muravyevskiy Park of the Sustainable Development, in the Antonovskoe and Khinganskoe 
forestries of the Khingan State Nature Reserve, in vicinities of Lake Dolgoe, village Ivanovka, village Bogoslovka, and nearby the town Blagoveshchensk. In most of the locations, the population status of the studied Liparis species was satisfactory. We noted a vital reproduction of the orchids. At the locations of Liparis populations, permanent study plots could be established for conducting long-term monitoring studies. The obtained data on the status of threatened plant populations will be used in the work on new editions of Red Data Books. On the studied sites of the Amur region, the presence of Liparis makinoana has not been confirmed by molecularphylogenetic data.

\section{Acknowledgements}

This study was financially supported by the Russian Science Foundation grant № 14-50-00029: collection of material in the Amur region, analysis of the material by morphological and molecular methods. We are grateful to the staff of the herbaria in MW, LE, MHA, ABGI, and the Herbarium of the Amur Branch of the Botanical GardenInstitute of FEB RAS for help in our study, and the staff of the Muravyevskiy Park of the Sustainable Development and Khingan State Nature Reserve for the assistance in conducting our field work.

\section{Supporting Information}

GenBank accession numbers and herbarium vouchers with indication of the sampling locations (Electronic Supplement 1: Voucher information and GenBank accession numbers for taxa used in this study), and a strict consensus tree derived using maximum parsimony analysis (Electronic Supplement 2: Phylogenetic relationship in Liparis as revealed by maximum parsimony analysis) may be found in the Supporting Information here.

\section{References}

Cameron K.M. 2005. Leave it to the leaves: a molecular phylogenetic study of Malaxideae (Epidendroideae, Orchidaceae). American Journal of Botany 92(6): 1025-1032. DOI: 10.3732/ajb.92.6.1025

Chen S.C., Liu Z.J., Zhu G.H., Lang K.Y., Ji Z.H., Luo Y.B., Jin X.H., Cribb P.J., Wood J.J., Gale S.W., Ormerod P., Vermeulen J.J., Wood H.P., Clayton D., Bell A. 2009. Orchidaceae. In: Z.Y. Wu, P.H. Raven, D. Hong (Eds.). Flora of China. St. Louis: Science Press, Beijing et Missouri Botanical Garden Press. Vol. 25. P. 211-235.

Cheng T., Xu C., Lei L., Li C., Zhang Y., Zhou S. 2016. Barcoding the kingdom Plantae: New PCR primers for ITS regions of plants with improved universality and specificity. Molecular Ecology Resources 16(1): 138-149. DOI: 10.1111/1755-0998.12438

Darman G.F. 2015. Flora of the Muravyevskiy Natural Park. Scholarly Notes of Transbaikal State University 60(1): 11-16. [In Russian]

Dressler R.L. 1981. The orchids: natural history and classification. Cambridge, Massachusetts: Harvard University Press. 356 p.

Dressler R.L. 1993. Phylogeny and classification of the orchid family. Portland: Cambridge University Press. 314 p.

Edgar R.C. 2004. MUSCLE: multiple sequence alignment with high accuracy and high throughput. Nucleic Acids Research 32(5): 1792-1797. DOI: 10.1093/nar/gkh340

Efimov P.G. 2010. The genus Liparis (Orchidaceae) in Russia. Botanicheskii Zhurnal 95(10): 1458-1480. [In Russian]

Felsenstein J. 1985. Confidence limits on phylogenies: an approach using the bootstrap. Evolution 39(4): 783 791. DOI: 10.1111/j.1558-5646.1985.tb00420.x

Gap S.O., Mi Y.C., Sun G.C., Myong G.C. 2001. Contrasting breeding systems Liparis kumokiri and $L$. makinoana (Orchidaceae). Annales Botanici Fennici 38(4): 281-284.

Hall T.A. 1999. BioEdit: a user-friendly biological sequence alignment editor and analysis program for Windows 95/98/NT. Nucleic Acids Symposium 41: 95-98.

Kim S.N., Kim Y.S. 1986. Morphological and cytological study on genus Liparis in Korea. Korean Journal of Plant Taxonomy 16(1): 59-88. DOI: 10.1007/s12374-010-9104-0

Kudrin S.G., Yakubov V.V. 2013. Illustrated Flora of the Khingan State Nature Reserve (Amur region): Vascular plants. Arkhara: Khingan State Nature Reserve. 335 p. [In Russian]

Lee C.S., Tsutsumi C., Yukawa T., Lee N.S. 2010. Two New Species of the Genus Liparis (Orchidaceae) from Korea Based on Morphological and Molecular Data. Journal of Plant Biology 53(3): 190-200. DOI: 10.1007/s12374-010-9104-0

Li L., Yan H. 2013. A remarkable new species of Liparis (Orchidaceae) from China and its phylogenetic implications. PLoS ONE 8(11): e78112. DOI: 10.1371/ journal.pone.0078112

Maekawa F. 1971. The wild orchids of Japan in colour. Tokyo: Seibundo Shinkousha. 495 p. [In Japanese]

Miskina L.V. 1971. Landscape complexes of the Arkhara Lowland and south-western spurs of the Small Khingan and prospects for their economic development. PhD Thesis. Khabarovsk. 248 p. [In Russian]

Nevskiy S.A. 1935. Genus Liparis L. C. Rich. In: Flora of the USSR. Vol. 4. Leningrad: AS USSR. P. 601-604. [In Russian]

Ohwi J. 1965. Flora of Japan. Washington: Square Press. 1067 p.

Rabotnov T.A. 1950. Problems of investigating the composition of populations for the phytocoenology purpose. In: Problems of Botany 1: 465-483. [In Russian] 
Red Data Book of the Amur region: Rare and Endangered Species of Animal, Plants and Fungi. Blagoveshchensk: Publishing House of the Far Eastern State Agrarian University, 2019. 501 p. [In Russian]

Red Data Book of the Russian Federation (plants and fungi). Moscow: KMK Scientific Press Ltd., 2008. 855 p. [In Russian]

Ronquist F., Teslenko M., van der Mark P., Ayres D.L., Darling A., Höhna S., Larget B., Liu L., Suchard M.A., Huelsenbeck J.P. 2012. MrBayes 3.2: efficient Bayesian phylogenetic inference and model choice across a large model space. Systematic Biology 61(3): 539-542. DOI: 10.1093/sysbio/sys029

Shibneva I.V. 2004. Liparis kumokiri (Orchidaceae) in the Russian Far East. Botanicheskii Zhurnal 89(10): 1633-1636. [In Russian]

Shibneva I.V. 2007. Notes on the Liparis (Orchidaceae) species from the Primorsky Krai. In: Plants in the monsoon climate. Vladivostok. P. 264-268. [In Russian]

Shibneva I.V. 2008. Species of the genus Liparis (Orchidaceae) in the south of the mainland part of the Russian Far East. In: Fundamental and applied problems of botany in early XXI century. Petrozavodsk. P. 148150. [In Russian]

Shibneva I.V. 2011. What are Liparis japonica (Miq) Maxim. and L. makinoana Schltr. (Orchidaceae) notes of the botanist. In: Protection and cultivation of orchids. St. Petersburg. P. 287-289. [In Russian]

Starchenko V.M., Darman G.F. 2002. Flora of the Botanical Garden of the Amur Scientific Centre FEB RAS. In: Introduction Centres of the Russian Far East, Research Results. Vladivostok: Dalnauka. P. 161-173. [In Russian]

Su Y.Y., Meng Y., Shi Y., Tang G.D., Liu Z.J. 2014. Liparis funingensis (Orchidaceae; Epidendroideae; Malaxidae), a new species from Yunnan, China: Evidence from morphology and DNA. Phytotaxa 166(1): 8593. DOI: 10.11646/phytotaxa.166.1.6

Su Y.Y, Huang Y.L., Chen L.J., Zhang P.W., Liu Z.J., Zhang G.Q. 2015. Liparis wenshanensis, a new orchid species from China: Evidence from morphological and molecular analyses. Phytotaxa 204 (4): 253-264. DOI: 10.11646/phytotaxa.204.4.2

Swofford D.L. 2003. PAUP*. Phylogenetic Analysis Using Parsimony (*and Other Methods): Version 4. Massachusetts: Sinauer Associates. 142 p.

Tatarenko I.V. 1996. Orchids of Russia: life forms, biology, conservation issues. Moscow: Argus. 207 p. [In Russian]

Terentieva E.I., Degtjareva G.V., Efimov S.V., Samigullin T.Kh., Varlygina T.I. 2016. The use of morphological and molecular methods to determine the species af- filiation of plants of the genus Liparis (Orchidaceae) in the Kedrovaya Pad State Nature Reserve. In: Problems of Botany in Southern Siberia and Mongolia. Barnaul: Publishing House of the Altai State University. P. 131-136. [In Russian]

Terentieva E.I., Degtjareva G.V., Efimov S.V., Samigullin T.Kh., Varlygina T.I. 2018. Taxonomic revision of the Liparis (Orchidaceae) species distributed in the Primorsky Krai and the Sakhalin region on the basis of the analysis of morphological and molecular data. In: Problems of Botany in Southern Siberia and Mongolia. Barnaul: Publishing House of the Altai State University. P. 440-444. [In Russian]

Terentieva E.I., Degtjareva G.V. Efimov S.V., Varlygina T.I. 2019. Species delimitation in Liparis (Orchidaceae) on the basis of the morphological and molecular data in the Muravyevskiy Park of the Sustainable Development. In: Problems of Botany in Southern Siberia and Mongolia. Barnaul: Publishing House of the Altai State University. P. 435-440. [In Russian]

Tsutsumi C. Yukawa T. 2008. Taxonomic status of Liparis japonica and L. makinoana (Orchidaceae); preliminary report. Bulletin of the National Museum of $\mathrm{Na}$ ture and Science, Series B 34(2): 89-94.

Tsutsumi C., Yukawa T., Lee N.S., Lee C.S., Kato M. 2007. Phylogeny and comparative seed morphology of epiphytic and terrestrial species of Liparis (Orchidaceae) in Japan. Journal of Plant Research 120(3): 405-412. DOI: 10.1007/s10265-007-0077-0

Tsutsumi C., Yukawa T., Kato M. 2008a. Liparis purpureovittata (Orchidaceae) - a new species from Japan. Acta Phytotaxonomica et Geobotanica 59(1): 73-77. DOI: 10.18942/apg.KJ00004899890

Tsutsumi C., Yukawa T., Lee N.S., Lee C.S., Kato M. 2008b. A new species of Liparis from Japan and Korea. Acta Phytotaxonomica et Geobotanic 59(3): 211-218. DOI: 10.18942/apg.KJ00005124835

Vakhrameeva M.G., Varlygina T.I., Tatarenko I.V. 2014. Orchids of Russia: biology, ecology and conservation. Moscow: KMK Scientific Press Ltd. 437 p. [In Russian]

Valiejo-Roman C.M., Terentieva E.I., Samigullin T.H., Pimenov M.G. 2002. Relationships among genera in Saniculoideae and selected Apioideae (Umbelliferae) inferred from nrITS sequences. Taxon 51(1): 91-101. DOI: $10.2307 / 1554966$

Varlygina T.I., Degtjareva G.V., Efimov S.V., Terentieva E.I. 2017. Population studies of the orchids in the Reserve Kedrovaya Pad. Biodiversity and Environment of Far East Reserves 1: 67-82. [In Russian]

Vyshin I.B. 1996. Orchids - Orchidaceae. In: Vascular plants of the Soviet Far East. St. Petersburg: Nauka. Vol. 8. P. 337-338. [In Russian] 


\title{
РЕВИЗИЯ И РАСПРОСТРАНЕНИЕ ВИДОВ РОДА LIPARIS (ORCHIDACEAЕ) В АМУ РСКОЙ ОБЛАСТИ (РОССИЯ)
}

\author{
Е. И. Терентьева ${ }^{1}$, Т. И. Варлыгина ${ }^{1}$, Г. Ф. Дарман ${ }^{2}$, \\ Г. В. Дегтярева ${ }^{1}$, С. В. Ефимов ${ }^{1}$, Т. Х. Самигуллин ${ }^{1}$ \\ ${ }^{1}$ Московский государственный университет имени М.В. Ломоносова, Россия \\ e-mail:el.terenteva@mail.ru,tat-varlygina@yandex.ru,efimov-msu@yandex.ru \\ ${ }^{2}$ Ботанический сад институт ДВО РАН, Россия \\ e-mail:gfdarman@yandex.ru
}

В июле 2018 г. на территории государственного природного заповедника «Хинганский» и Муравьёвского парка устойчивого развития было проведено обследование популяций видов рода $L i$ paris и первичное определение растений. Род Liparis остается одним из наиболее сложных в систематическом отношении в семействе Orchidaceae. Наблюдения в природе, изучение гербарных сборов и литературных данных показывают значительную внутривидовую вариабельность морфологических признаков. Поэтому для оценки видовой принадлежности представителей природных популяций были взяты фрагменты растений для молекулярно-филогенетических исследований. Всего в анализ было включено 110 образцов. В качестве молекулярного маркера были выбраны ядерные последовательности межгенного участка (ITS1-5.8S-ITS2) транскрибируемого рибосомного оперона. На молекулярно-филогенетическом дереве образцы из исследуемых популяций формируют отдельные хорошо поддержанные клады, что подтверждает их естественность. ITS последовательности анализируемых растений каждой клады имеют группоспецифические замены, которые маркируют их положение на филогенетическом дереве. Анализ морфологических признаков в совокупности с молекулярными данными позволил провести видовую идентификацию растений из рода Liparis. На территории Амурской области, согласно флористическим сводкам, были отмечены два вида (Liparis japonica и L. makinoana). Изучение популяций Liparis, найденных в природе, а также результаты анализа морфологических и молекулярных данных показали, что на исследуемой территории, кроме L. japonica и L. makinoana произрастает L. kumokiri, а также еще один вид, возможно, являющийся новым для науки. Уточнено распространение этих видов на обследованных нами территориях Амурской области, а также выявлены их новые местонахождения. Состояние ценопопуляций изученных видов в большинстве мест обитания было удовлетворительным. Отмечено хорошее плодоношение и наличие возобновления. В местах их произрастания могут быть заложены пробные площади для проведения мониторинговых исследований. Полученные данные о состоянии популяций редких видов будут использованы при подготовке новых изданий красных книг. На обследованных нами территориях Амурской области наличие Liparis makinoana не подтверждено молекулярными данными.

Ключевые слова: Красная книга, молекулярные исследования, морфологические признаки, особо охраняемая природная территория, редкие виды, состояние ценопопуляций, филогения 